\title{
Federal legal authorities for the early detection of and rapid response to invasive species
}

\author{
Jhoset Burgos-Rodríguez $\cdot$ Stanley W. Burgiel
}

Received: 3 November 2019/Accepted: 3 November 2019/Published online: 31 December 2019

(C) The Author(s) 2019

\begin{abstract}
The ability of federal agencies to carry out actions or programs is based on their legal authorities. Efforts to improve federal capacities for the early detection of and rapid response to invasive species (EDRR) require careful delineation of legal authorities, regulations, and policies that would enable or limit EDRR. Building on information provided by federal agencies and an inspection of the US Code and the Code of Federal Regulations, we review and identify relevant authorities to determine federal legal capacities, gaps, and inconsistencies to address EDRR. The EDRR process can be examined in the context of four categories, including (1) explicit invasive species authorities, (2) emergency authorities that could be
\end{abstract}

This document is not a legal opinion. It is not intended to and does not create any rights or benefit enforceable by any party against the US government, nor does it necessarily represent the official position of the US government.

Electronic supplementary material The online version of this article (https://doi.org/10.1007/s10530-019-02148-w) contains supplementary material, which is available to authorized users.

J. Burgos-Rodríguez $(\bowtie)$

School of Law, University of Puerto Rico, 7 Ave.

Universidad, San Juan, PR 00925, USA

e-mail: jhoset.burgos@upr.edu

S. W. Burgiel

National Invasive Species Council Secretariat c/o Office of the Secretary, U.S. Department of the Interior, 1849 C Street NW, MS2061, Washington, DC 20240, USA triggered during a crisis or serve as models for enhanced invasive species EDRR authorities, (3) supporting authorities that could be used under agency discretion, and (4) constraining authorities and legal requirements. Although the Plant Protection Act and the Animal Health Protection Act are comprehensive authorities that address the detection of and response to organisms that threaten plant and livestock health, there is no single authority that encompasses EDRR for all invasive species. Rather, there is a patchwork of authorities that unevenly addresses various aspects of EDRR. In addition to gaps in authority, EDRR efforts could be constrained by environmental compliance, as well as subnational governance and private rights. Although some of these gaps could be closed through legislation, others need to be addressed using the discretionary power of federal agencies and their ability to establish cooperation mechanisms with private and subnational entities.

Keywords Early detection and rapid response (EDRR) · Guidance · Invasive species · Law · Legal authority $\cdot$ Policy $\cdot$ Regulation $\cdot$ Statute

\section{Introduction}

According to the United States government, invasive species means "with regard to a particular ecosystem, 
a non-native organism whose introduction causes, or is likely to cause, economic or environmental harm, or harm to human, animal, or plant health" (Executive Office of the President 2016). Invasive species represent one of the most significant threats to ecosystems (Pimentel et al. 2005); human, animal, and plant health (Pejchar and Mooney 2009; Pyšek and Richardson 2010); infrastructure (Invasive Species Advisory Committee 2016); food production systems (Pejchar and Mooney 2009); military readiness (Meyerson and Reaser 2003; US Department of Defense 2017), the economy (Pimentel 2011); and cultural resources (McNeely 2001; Pejchar and Mooney 2009; US Department of the Interior 2016). Recognizing these impacts, the US government has maintained a policy to prevent the introduction, establishment, and spread of invasive species, as well as to eradicate and control populations of invasive species (Executive Order (E.O.) 13112 as amended by E.O. 13751; Executive Office of the President 1999, 2016). This broad policy statement is underwritten by a range of legal authorities that guide more specific action relevant to particular agencies and invasive species threats. Previous analyses of federal legal authorities related to invasive species provide a general reference point for the analysis presented here (US Government Accountability Office 2001; NISC 2001a; Miller and Fabian 2004; Graham 2011; Corn and Johnson 2013, 2015; Committee on the Movement of Aquatic Invasive Species onto and off of Federal Lands and Waters 2015; Johnson et al. 2017).

In response to a directive in the 2016-2018 National Invasive Species Council (NISC) Management Plan, we examine authorities and policies that either enable or act as barriers to the early detection of and rapid response to invasive species (EDRR) with a view towards building national capacity for EDRR. Reaser et al. (2019, this issue) define EDRR as a "guiding principle for minimizing the impact of invasive species in an expedited yet effective and cost-efficient manner, where detection is the process of observing and documenting an invasive species and response is the process of reacting to the detection once the organism has been authoritatively identified and response options assessed." Legal and policy frameworks underpin federal engagement and actions across the components embodied in the systemic approach to EDRR (Reaser et al. 2019, this issue). Most notably, they influence where, what, when, how, and by whom detection and response measures are enacted (Morisette et al. 2019, this issue).

Although the focus of our work is on relevant federal laws and policies, we recognize that the federal government, as delineated by the US Constitution, has limited enumerated powers and is intended to function in concert with the authorities granted to states, territories, and tribes, as well as individual rights (e.g., property rights). Herein, we recognize the relevance of laws and policies at both the subnational (e.g., states, territories, tribes, counties, water districts) and international levels (e.g., treaties, agreements, soft law; Shine et al. 2000; Environmental Law Institute 2002, 2004, 2010; Miller 2003; Miller and Fabian 2004; Young 2006; Environmental Law Institute and the Nature Conservancy 2007; Otts and Nanjappa 2016), but they are beyond the scope of this paper.

Invasive species law and policy overlay an institutional landscape, composed of numerous departmental and inter-departmental bodies and programs. A recent analysis by the Congressional Research Service (CRS) identifies at least 32 federal agencies with shared responsibilities for invasive species prevention, eradication, and control efforts or programs (NISC 2001b; Johnson et al. 2017). Some of these agencies are defined by statute, while others are created to run programs or address particular needs. Recognizing that this landscape is subject to change, the present analysis focuses specifically on the legal, and not the institutional, aspects of EDRR.

In order to implement the NISC management plan directive, the NISC Secretariat invited the federal bodies represented by Council leadership to respond to a request for information on federal EDRR legal authorities, gaps, and inconsistencies (see supplementary material (SI 1) associated with Reaser et al. 2019, this issue). Agency responses varied in terms of content and level of detail but provided a starting point for the analysis. To build and expand on the agencyprovided information, we reviewed 54 titles of the US Code (USC) using LexisNexis and the Legal Information Institute to identify federal authorities related to invasive species EDRR. Using the statutes' associated notes, we then searched the Code of Federal Regulations (CFR) and relevant judicial decisions for additional information. To determine relevant content, we used terms that relate to EDRR operations, EDRR supporting tools, and invasive species (Table 1). As such, this assessment aims to provide a comprehensive 
overview of applicable US statutes and regulations, while recognizing that it is not exhaustive given the numerous authorities that touch upon some aspect of invasive species.

This assessment explores a range of authority types including those specific to invasive species, as well as broader statutes and regulations that could be applicable even though invasive species are not explicitly referenced. In the latter case, many of the invasive species-related authorities were not enacted with the specifics of EDRR in mind. However, given the critical need to address new invasions, federal agencies have identified means to use these authorities to incorporate aspects of EDRR into their activities.

Legal interpretations can change over time with input from the judicial system and Congress, as well as agency experience with policy implementation and scientific advances. This paper is intended as a catalog and non-prescriptive analysis of authorities that are directly and indirectly relevant to EDRR. A more thorough evaluation of their efficacy in implementation, funding availability/appropriations, reauthorization, resource allocation, and agency prioritization is beyond the scope of this assessment. The attending guidance on authorities in this volume (BurgosRodríguez and Burgiel 2019, this issue) provides more direction on addressing gaps in existing legal capacities.

The legal context for invasive species ${ }^{1}$

While the US Constitution does not explicitly mention invasive species, it grants Congress authority to legislate, appropriate funds, and authorize federal agencies to take action and issue rules and regulations that may include invasive species. As a result, the executive branch can create policy, guidelines, and programs related to invasive species. Explicit legislation authorizing federal agencies to address harmful and potentially harmful non-native species has been present in the US legal system since the turn of the twentieth century with the enactment of the Lacey Act

\footnotetext{
${ }^{1}$ This assessment includes numerous references to the US Code and the Code of Federal Regulations, which can be viewed through services provided by the US House of Representatives (http://uscode.house.gov/browse.xhtml, accessed 5 September 2019) or the Legal Information Institute (https://www.law. cornell.edu, accessed 5 September 2019).
}

of 1900 (16 USC $\S \S 3371-3378,18$ USC $\S \S 42-43)$ and the Terminal Inspection Act of 1916 (7 USC \$7760). However, each federal department or agency relies on different legal authorities. No holistic legislation for invasive species prevention, eradication, control, and coordination across all taxa has ever been enacted. Reports dating back 25 years consistently describe the legal status of federal invasive species programs as fractured and incomplete, resulting in a patchwork of laws, regulations, policies, and programs (Office of Technology Assessment 1993; Miller 2004; Environmental Law Institute 2007; Corn and Johnson 2013; Graham 2011; Johnson et al. 2017). For example, authorities may allow for action on federal but not non-federal lands. Authorities may apply to some categories of invasive species (e.g., those affecting plant health or livestock health), but not others (e.g., those affecting infrastructure or wildlife health). The piecemeal nature of the US system can undermine the effectiveness of efforts to address invasive species, particularly EDRR (US Government Accountability Office 2001) and contrasts with more comprehensive approaches employed outside of the United States such as in New Zealand and the European Union (Public Act 1993, 1996; European Commission 2014).

Despite these limitations, it is still possible to conduct a fairly thorough assessment of existing authorities and examine opportunities to cover gaps and inconsistencies. A number of statutes have been enacted to directly address invasive species. Many of these statutes are focused on a particular species, geographical area, industry, or pathway that has already proven to be a risk and are thus inherently reactive. Authorities to address invasive species are also divided jurisdictionally across federal agencies and subnational governments as well as topically by species and sectors of concern. There are also numerous statutes that when interpreted more expansively could allow federal agencies and departments to address issues related to invasive species and EDRR (Miller 2004; Johnson et al. 2017). Recognizing these differing levels of specificity and focus, we analyzed relevant authorities across four different categories:

Category 1 Explicit invasive species authorities, including those addressing EDRR programs or actions, as well as those that could be interpreted to allow EDRR programs or actions. 
Table 1 List of search terms related to EDRR operations, EDRR supporting tools, and invasive species

\begin{tabular}{|c|c|c|c|}
\hline Cooperative agreements & Environmental compliance & Monitoring & Regulation \\
\hline \multicolumn{4}{|l|}{ EDRR operations } \\
\hline Coordination & Eradication & Planning & Response \\
\hline Data & Horizon scanning & Preemption & Risk assessment \\
\hline Early detection & Identification & Quarantine & Staffing \\
\hline Emergency & Inspection & Rapid detection & Surveillance \\
\hline Enforcement & Major disaster & Rapid response & Terrorism \\
\hline \multicolumn{4}{|l|}{ EDRR supporting tools } \\
\hline Conservation & Maintenance & Outreach & Restoration \\
\hline Control & Innovation & Research & Training \\
\hline \multicolumn{4}{|l|}{ Invasive species } \\
\hline Alien species & Disease infestation & Invasive insect & Pathogen \\
\hline Aquatic nuisance species & Exotic and endemic animal disease & Invasive species & Pest injurious to agriculture \\
\hline Bioagent & Exotic weed & Nonindigenous aquatic nuisance & Pest \\
\hline Biological agent & Exotic & Nonindigenous species & Plant pest \\
\hline Biological attack & Infectious agent & Non-native invasive species & Predator \\
\hline Biological control organisms & Injurious & Nonnative species & Prohibited wildlife \\
\hline Bioterrorism & Insect infestation & Noxious weeds & Undesirable plant \\
\hline Damaging agents & Insect & Nuisance species & Weed \\
\hline Disease & Invasive brush & Parasitic plant & Zoonotic diseases \\
\hline
\end{tabular}

Category 2 Emergency authorities that are not explicitly designed for, but could include, EDRR actions for invasive species under certain circumstances or could serve as models for enhanced invasive species EDRR authorities.

Category 3 General authorities that, under the discretion of agencies, could include EDRR actions, as well as those that could explicitly support specific aspects of EDRR.

Category 4 Constraining authorities and legal requirements that may entail certain assessments or additional review prior to initiating EDRR actions.

The supplementary material associated with this article (SI 2, this issue) contains a list of the authorities referenced below, and in some cases (e.g., Category 3 ), a more comprehensive listing.

\section{Category 1: Invasive species authorities}

There are a limited number of legal authorities that allow for the detection of and response to invasive species. These authorities can be explicit as in the case of the Plant Protection Act (PPA) (7 USC $\S \S 7701$ et seq.) and the Animal Health Protection Act (AHPA) (7 USC $\S \S 8301$ et seq.), or provide discretionary authority for detection or response when authorized to carry out prevention, eradication, and/or control. Some of these authorities are pathway oriented as in the case of mail inspection and ballast water or species-specific as in the case of brown tree snakes (Boiga irregularis) and "undesirable bees." The remainder cover multiple EDRR elements for numerous types of organisms such as plant "pests" and diseases, as well as livestock diseases. Although many of these authorities are under the US Department of Agriculture (USDA) in relation to agricultural goods or forests, some include nonagricultural related organisms and non-federal lands.

Category 1 covers invasive species authorities that reference invasive species and/or relevant subcategories (e.g., non-native plant pests and animal diseases) in the context of EDRR programs or actions. In 
some cases this also includes programs or actions that could readily be interpreted to encompass EDRR. This section includes authorities related to executive orders, plant protection, animal health, inspections, forest health, aquatic invasive species, and additional wildlife or species specific authorities.

\section{Executive orders}

Under E.O.s 13112 and 13751, federal agencies can use relevant agency programs and authorities to detect and respond rapidly to eradicate or control populations of invasive species in a manner that is cost-effective and minimizes human, animal, plant, and environmental health risks. In addition, they can promote public education and action on invasive species, their pathways, and response measures, with an emphasis on prevention and EDRR. Finally, NISC is charged with advancing national incident response, including EDRR (Executive Office of the President 1999, 2016). In practice, E.O. 13112 has been explicitly used by a number of agencies as an authority to support the development of regulations (33 CFR 148.737, 23 CFR pt. 773 app. A, 43 CFR 46.215).

\section{Plant health}

The Plant Protection Act of 2000, as amended (PPA) (7 USC $\$ \$ 7701$ et seq.), provides for the regulation of the movement of plant pests, plants, and plant products, as well as for quarantine procedures, declaration of emergencies, inspection, eradication, creation of agreements, and enforcement. PPA authorizes inspection of any person, means of conveyance, or premises carrying or believed to be carrying any plant, plant product, biological control organism, plant pest, noxious weed, or article moving into the United States, moving in interstate commerce, or intrastate commerce from or within any state, portion of a state, or premises quarantined as part of an extraordinary emergency declared under PPA (7 USC \$7715, 7 CFR 330.105). PPA provides the authority to declare an extraordinary emergency due to the presence of a plant pest or noxious weed that is new to or not known to be widely prevalent in the US and that threatens plants or plant products (7 USC $\$ 7715,7$ CFR 330.106). Such a declaration provides USDA broad funding and response authority, including the authority to hold, seize, treat, apply other remedial measures to destroy, or otherwise dispose of such items, as well as authority to quarantine items, premises, and states or portions of thereof to prevent dissemination of or eradicate the plant pest or noxious weed (7 USC \$7715, §7772, 7 CFR 301.1 et seq). Other remedial actions are authorized to prevent the dissemination of certain plant pests or noxious weeds new to or not known to be widely prevalent in the United States (7 USC §7714). Also, some USDA functions relating to agriculture import and entry inspection activities are transferred to the Department of Homeland Security (DHS) (see 6 USC §231, §551[d], §552[d], and §557, and the DHS Reorganization Plan of Nov. 25, 2002, which appears as 6 USC $\$ 542$ note).

\section{PPA supports the development of programs and activities related to}

- identification and mitigation of threats to the domestic production of crops (7 USC \$7721), including the development of plant pest risk assessment standards for certain products (7 CFR 319.40-11);

- control and eradication of noxious weeds, including technical assistance to certain weed management entities (7 USC $\$ 7781$ et seq.);

- an audit-based certification system and a nursery plant pest risk management system in collaboration with industry, states, and local growers (7 USC §7721);

- an early plant pest detection and surveillance improvement program in consultation with the National Plant Board (7 USC \$7721); and

- a Plant and Disease Response Fund to support emergency eradication and research activities in response to economic and health threats posed by pests and diseases affecting agricultural commodities under PPA and the AHPA (7 USC \$8321).

While PPA is fairly broad, more specific legal provisions relevant to the management of invasive plants, cooperative efforts, and regulation of seeds are included in the Federal Noxious Weed Act of 1974, the Noxious Weed Control and Eradication Act of 2004, and the Federal Seed Act. 


\section{Animal health}

The Animal Health Protection Act of 2002, as amended (AHPA) (7 USC $\S \S 8301$ et seq.) consolidates a number of animal quarantine and related authorities resulting in the primary federal authority governing animal health (Johnson et al. 2017). AHPA provides for the regulation of the movement of any animal or related material necessary to prevent the spread of livestock pests or diseases, as well as quarantine procedures, declaration of emergencies, inspection, eradication, creation of agreements, and enforcement. AHPA has a broad definition of movement including mailing, shipping, and release to the environment (7 USC §8302). The USDA may carry out operations and measures to detect any pest or disease of livestock (e.g., drawing of blood, diagnostic testing of animals), including animals at a slaughterhouse, stockyard, or other points of concentration (7 USC §8308). It also authorizes inspection of any person, means of conveyance, or premises carrying or believed to be carrying a regulated animal or article moving into the United States, moving in interstate commerce, or intrastate commerce from or within any state, portion of a state, or premises quarantined as part of an emergency (7 USC §8307). USDA is designated as the lead agency with respect to issues relating to pests and diseases of livestock (7 USC $§ 8310$ ), while the Department of Health and Human Services (HHS) is designated as the surveillance coordinator for zoonotic diseases (7 USC §8319).

As with PPA, a key component of AHPA is the authority to declare an extraordinary emergency triggered by the presence of a pest or disease that threatens US livestock (7 USC §8306, 8316). Under the emergency, USDA can fund, hold, seize, treat, or apply other remedial actions to destroy or dispose of any animal, article, facility, or means of conveyance. In addition, USDA can prohibit or restrict the movement or use within a state, or any portion of a state of any animal or article, means of conveyance, or facility. USDA can take such actions only on finding that subnational governments are unable to control or eradicate a pest or disease after consultation with them. Herein, USDA is authorized to carry out operations and measures to control and eradicate any pest or disease of livestock (7 USCS $§ 8308,9$ CFR ch.1 subch. B). AHPA control and eradication authorities can also be used for the detection, control, and eradication of aquaculture diseases (7 USC $\S 8322)$.

AHPA supports the development of programs and activities related to

- preclearance agreements of animals or articles at locations outside the US moving into the country ( 7 USC $§ 8311$ );

- a record-keeping system to provide for the reliable tracking of animal and plant shipments (7 USC $\S 8320)$;

- coordinated detection and response to carry out operations and measures to detect, control, or eradicate any pest or disease of livestock, including funding to cooperating industries and states (7 USC §8308) and for veterinary training (7 USC $\S 8319)$; and

- a network of national animal health laboratories to enhance capability to respond to bioterrorist threats to animal health, provide capacity for standardization, and develop and coordinate veterinary diagnostic laboratory capabilities (7 USC $§ 8308 a$ ).

Other legal provisions relevant to the management of predatory wildlife and veterinary biological products for animal disease are included in the Animal Damage Control Act and the Virus-Serum-Toxin Act.

\section{Additional inspection authorities}

In addition to PPA and AHPA, a number of authorities provide for the inspection of certain agricultural products, wildlife, goods, cargo, people, or means of conveyance which could be pathways of introduction or disease vectors. Most inspection authorities are fragmented among different agencies, statutes, and regulations. One of these authorities, the Terminal Inspection Act (TIA) of 1916 (7 USC $\$ 7760$ ) is one of the oldest pieces of EDRR-related legislation. A number of statutes and regulations related to the TIA, as well as the Lacey Act, the Alien Species Prevention and Enforcement Act of 1992, and security related authorities for DHS and the Transportation Security Administration (TSA) authorize EDRR activities; establish and prohibit nonmailable articles; authorize the prohibition and enforcement of wildlife importation; and allow for the inspection of 
passengers, cargo, and agricultural products imported to the United States and/or in interstate commerce.

\section{Forest health}

Invasive species can affect forest health in a variety of ways, including through insect infestations, forest diseases, as well as changes in soil composition and wildfire regimes (Wingfield et al. 2015; Boyd et al. 2013). There are multiple authorities addressing the detection and response to these threats. Some of these authorities include the Healthy Forest Restoration Act of 2003 (HFRA), the Cooperative Forestry Assistance Act of 1978 (CFAA), and the Hawaii Tropical Forest Recovery Act of 1992. CFAA authorizes USDA to protect certain trees and forests on USDA land and other federal and non-federal land from natural and man-made causes of harm (16 USC \$2104). The HFRA addresses multiple aspects of forest health including fuel reduction, improving the capacity for early detection of insect and disease infestations, and promoting systematic gathering of information to address the impact of insect and disease infestations and other damaging agents on forest and rangeland health (16 USC $\$ 6501$ et seq.). HFRA also provides for cooperation and assistance in developing treatments and strategies to reduce susceptibility of forests to severe infestation and diseases, and financial assistance to subnational governments for hazardous fuel reduction activities (16 USC $\$ 6508,6553$ ).

\section{Aquatic invasive species}

Authorities addressing aquatic invasive species include the Nonindigenous Aquatic Nuisance Prevention and Control Act of 1990 (NANPCA), as amended by the National Invasive Species Act of 1996 (NISA), and the River and Harbor Act of 1958, as amended by the Water Resources Reform and Development Act of 2014. NANPCA created the Aquatic Nuisance Species (ANS) Task Force (known as ANSTF), which is charged with developing and implementing a program for waters of the United States "to prevent introduction and dispersal of aquatic nuisance species; to monitor, control, and study such species; and to disseminate related information" (16 USC §4721). NANPCA also calls for a range of research and capacity support components including state management plans, species control plans, formation of regional panels, and programs focused on the zebra mussel (Dreissena polymorpha) and brown tree snake.

NANPCA includes reference to early detection in the context of monitoring, but does not reference rapid response (16 USC §4722). The Aquatic Nuisance Species Program (ANS Program) was finalized in July 1994. It provides significantly more detail to the charge within NANPCA to prevent, monitor, and control aquatic nuisance species, including aspects more specifically related to EDRR. With regard to the delegation of authorities across ANSTF membership, NANPCA provides the US Fish and Wildlife Service (USFWS), National Oceanic and Atmospheric Administration (NOAA), and the US Coast Guard with the authority to implement the ANS Program, and other agencies on the Task Force with sufficient authority or jurisdiction from other sources (e.g., PPA) can support implementation (16 USC §4722). ANSTF and associated federal agencies have used the discretion under NANPCA and other authorities to take on EDRR efforts to fulfil their individual missions.

Additionally, NANPCA, NISA, the Clean Water Act of 1972, and the Vessel Incidental Discharge Act of 2018 specifically address the regulation of ballast water as a potential pathway for the introduction of invasive species. These regulations focus more on acceptable standards for treatment of ballast water than on authorizing EDRR actions in the event of a potential introduction.

\section{Wildlife and specific species}

There are additional invasive species authorities that focus on wildlife collectively and/or particular species. Although these authorities do not necessarily provide for comprehensive EDRR programs, in many cases they could provide for EDRR elements such as detection or eradication. For example, the John D. Dingell, Jr. Conservation, Management, and Recreation Act of 2019 authorizes certain federal departments to plan and carry out activities on their land to protect water and wildlife by managing invasive species. This can includes eradication and population control, as well as research on EDRR methods (P.L. 116-9). Alternatively, provisions in the Lacey Act are focused on preventing the introduction and movement of injurious species by a listing process that prohibits import of injurious wildlife (18 USC $\S 42[a]-[b]$ ). The Act authorizes destruction and enforcement including 
search and seizure related to the movement of listed species (18 USC §42; 16 USC §3375).

There are also numerous species specific authorities that may include aspects related to EDRR, including: honeybees (7 USC $\S \S 281$ et seq.; 7 CFR pt. 322), brown tree snakes (7 USC $\S \S 8501$ et seq.; 16 USC $\S 4728)$, depredating and otherwise injurious birds (16 USC $\$ \$ 703$ et seq., 50 CFR 21.41 et seq.), nuisance mammals and birds, constituting reservoirs of zoonotic diseases (7 USC §8353), cotton insects (7 USC $\S 1444 a)$, crown of thorns starfish (Acanthaster planci) (16 USC $\S \S 1211$ et seq.), jellyfish and other such harmful species (16 USC $\S \S 1201$ et seq.), mosquitoes (42 USC \$247b-21), wild horses (Equus caballus) and burros (Equus africanus asinus) (16 USC §1333, 36 CFR 222.69), sea lamprey (Petromyzon marinus) (16 USC §\$931 et seq., §941c, §757b; 33 USC \$2309a; 16 USCS $\$ 1274$ notes), sudden oak death (7 USC $\$ 7720$ ), and water hyacinth (Eichhornia crassipes), alligator grass (Alternanthera philoxeroides), and chestnut plants (Trapa natans) (18 USC §46).

The segmentation of authorities described above reflects a patchwork approach to invasive species related to different sectors (e.g., plant and animal health), ecosystems (e.g., forest health), and particular species (e.g., aquatic nuisance species, injurious wildlife). These authorities also allow for different degrees of action related to EDRR activities. For example, authorities under PPA and AHPA extend from monitoring and inspection to emergency response. In other areas, such as with aquatic invasive species those types of authorities are not as discrete, or in many cases the initial intent of the legislation was not for EDRR per se. Finally, these authorities are distributed across a range of departments, including DHS, USDA, Department of the Interior (DOI), US HHS, and the US Environmental Protection Agency (EPA), which may require additional efforts for interagency communication and coordination.

\section{Category 2: Emergency authorities}

Category 2 addresses types of emergency authorities that are not explicitly designed for, but could include, EDRR actions for invasive species under certain circumstances or could serve as models for enhanced invasive species EDRR authorities. This section covers authorities related to major disasters (with subsections on agricultural biosecurity, wildfire, and bioterrorism and weapons of mass destruction) and public health services and emergencies.

The US government has multiple emergency programs that involve some form of preparing for, detecting, and responding to a "crisis" event, which can be analogous to EDRR for invasive species. Examples include natural disasters, wildfire, bioterrorism, and pest and disease outbreaks. These national programs generally have robust legal frameworks that allow them to address multiple known and unknown scenarios. Often they are based on a primary piece of legislation that serves as a foundation, which can be modified over time with additional legislative amendments. They can address a broad range of authorities including collaboration with federal agencies and subnational governments, capacity building and training, flexibility in funding, consideration of subnational jurisdictions and private citizen's rights, declaration of emergencies, research, and considerations for environmental compliance. These components are essential elements designed to prepare, detect, assess, and respond to threats.

Authorities under bioterrorism, agricultural biosecurity, and public health emergencies explicitly address biological organisms. Some of these organisms are considered or may be associated with invasive species (e.g., certain disease vectors). Other authorities under this category, while not specific to invasive species, can readily be interpreted to apply. Invasive species have the potential to create a major disaster, cause agricultural and nonagricultural emergencies or epidemics, cause a public health emergency, or be used as a tool for biological warfare (Meyerson and Reaser 2003). Even if the direct applicability of these authorities to EDRR is limited to extreme events, they can serve as models for EDRR efforts. Other models include the Nuclear Incident Response Team; National Urban Search and Rescue Response System; Visible Intermodal Prevention and Response Teams; Hazardous Substance, Pollutant, or Contaminant Response; and Marine Mammal Health and Stranding Response Program. The following two sections examine authorities related to major disasters, emergencies, and public health emergencies.

\section{Major disasters and emergencies}

The Homeland Security Act of 2002 (HSA) and the Robert T. Stafford Disaster Relief and Emergency 
Preparedness Act of 1988 serve as the legislative foundation for disaster authorities, which have been supplemented by a number of additional statutes. HSA and complementary authorities establish a broad framework for DHS leadership in emergency preparedness response to a range of threats. DHS is thereby responsible for coordinating and leading the nation's efforts to prepare for, respond to, recover from, and mitigate against the risk of all hazards (6 USC §314). This includes the planning and development of common capabilities necessary to address a range of threats, including natural disasters, catastrophic incidents, acts of terrorism, and other manmade disasters.

HSA and related acts establish the basic coordination functions for DHS and the Federal Emergency Management Agency (FEMA). This includes planning [i.e., national preparedness plan, coordinated response plan, national disaster recovery strategy (6 USC $\$ 741$ et seq.; 6 USC §314; 6 USC \$771)] and the development of a national preparedness system and national incident management system with federal, state, and local governments, to respond to such attacks and disasters (6 USC $\$ 314,744$; see also Burgiel 2019, this issue). It also includes building capacity with partners through the provision of funding, training exercises, technical assistance, planning, and other assistance to build tribal, local, state, regional, and national capabilities necessary to respond to a natural disaster, act of terrorism, or other man-made disaster (6 USC $\$ 313$ et seq.)

The Stafford Act of 1988 provides broad authority to the president of the United States to declare a major disaster or emergency, triggering access to federal technical, financial, logistical, and other accelerated assistance by affected subnational governments. Invasive species could conceivably fit under the definition of major disaster, emergency, or catastrophic incident particularly in terms of agroterrorism, bioterrorism, or as an underlying driver of wildfire. Wildfire and bioterrorism as distinct threats are covered under these acts, but they are also covered by other, more specific authorities. Although many of these impacts, particularly for agricultural biosecurity, could be covered under the PPA or AHPA (see Category 1), emergencyrelated authorities could help address any gaps (e.g., non-livestock animals) and expand the availability of rapid response resources.
The Stafford Act authorizes the use of technical and financial pre-disaster hazard mitigation assistance to improve the assessment of vulnerability to natural hazards (42 USC §5133). In addition, it authorizes recovery activities including disaster impact assessments (42 USC §5170a). The National Infrastructure Simulation and Analysis Center is also authorized to support threat assessment for critical infrastructure (42 USC \$5195c). The president has extensive authority to provide major disaster (42 USC \$5170a) and emergency assistance (42 USC §5192) using any federal agency authority and resources (including personnel, equipment, supplies, facilities, and managerial, technical, and advisory services). Finally, in the specific case of nonindustrial private forest lands, USDA can provide financial assistance to owners who implement emergency measures for restoration purposes in the wake of a natural disaster (16 USC \$2206). Herein, USDA used its discretion to include insect and disease infestations in their interpretation of the definition of natural disaster (16 USC §2206; 7 CFR 701.2).

There are also complementary and additional emergency authorities for particular types of threats, including agricultural biosecurity, bioterrorism and weapons of mass destruction, and wildfire. Many of these are also addressed by the National Biodefense Strategy (Executive Office of the President 2018), which provides a framework to coordinate federal efforts addressing biological threats.

\section{Public health services and emergencies}

In addition to the major disasters described above, there are multiple statutes addressing public health emergencies. These primarily include the Public Health Service Act of 1944 and the Public Health Security and Bioterrorism Preparedness and Response Act of 2002. Taken together these statutes provide a comprehensive legal framework for preventing, preparing for, detecting, assessing, and responding to public health emergencies associated with disease outbreaks or bioterrorist attacks. As with the previous section, these public health authorities can apply to a particular subset of invasive species (e.g., non-native pathogens and their vectors), while also serving as a general example of a more comprehensive approach to EDRR.

Most of the authorities outlined in these statutes relate to HHS, which is mandated to lead federal 
public health and medical response to public health emergencies and incidents. Responsibilities include preparing the National Health Security Strategy and an implementation plan for public health emergency preparedness and response. Such activities can include integration of public and private medical capabilities with other first responder systems, capacity building, coordination, continuity of operations, strategic initiatives to advance countermeasures, and medical and public health community resilience (42 USC $\$ 300 \mathrm{hh}-$ 1).

HHS is also authorized to develop and implement a plan under which personnel, equipment, medical supplies, and other resources may be effectively used to control epidemics of any disease or condition and to meet other health emergencies or problems (42 USC $\S 243)$. These activities can be further supported through HHS's issuance and enforcement of regulations necessary to prevent the introduction, transmission, or spread of communicable diseases (42 USC $\S 264)$, as well as support for research and innovation in the areas of public health emergencies (42 USC \$247d-7e; 42 USC §2851-6). HHS may conduct inspection of animals or articles to prevent the introduction, transmission, or spread of communicable diseases from foreign countries (42 USC \$264), and is mandated to establish and maintain a list of biological agents that have the potential to pose a severe threat to public health and safety (42 USC \$262a).

Finally, HHS is generally authorized to declare, fund, respond to, and "take such action as may be appropriate" to address public health emergencies caused by disease, outbreak of infectious diseases, or bioterrorist attack in line with its National Response Strategy. This includes deployment of emergency response teams (42 USC \$247d); prohibition of the entry of certain persons, property, animals, and articles from foreign countries (42 USC $\$ 265 ; 42$ CFR 71.63); and establishment and enforcement of interstate and foreign quarantines to prevent the spread of a communicable disease (42 USC $\$ 264$ et seq.; 42 CFR 70.1 et seq.; 42 CFR 71.1 et seq.). HHS can cooperate with subnational authorities in the enforcement of federal and subnational quarantine regulations as well as other subnational health regulations (42 USC §243), and it can also temporarily reassign state and local public health department or agency personnel funded through programs authorized under the Public Health Service Act (42 USC §247d).
Category 3: General and supporting authorities

Category 3 includes general authorities that under the discretion of agencies could include EDRR actions, as well as those that could support specific activities in the EDRR system. Currently, federal land management agencies use general authorities to address invasive species. These authorities were not necessarily enacted to specifically address invasive species, but they could be interpreted to allow agencies to take EDRR-related actions in some contexts. This category includes federal agencies' enabling/organic acts (i.e., those pieces of legislation that establish an agency's basic authority over a particular issue or selection of federal lands), as well as authorities related to cultural and natural resource conservation, preservation, restoration, management, and maintenance.

As highlighted in the other assessments in this Special Issue, EDRR activities are not limited to physical detection and response. These efforts are built on and complemented by a range of supporting activities, resources, and tools that underpin effective EDRR. These can include research and innovation, funding, staffing, ability to create cooperative agreements, enforcement, and resource acquisition. There are particular legal authorities that enable the development and implementation of such tools across the full suite of EDRR actions.

This section includes general authorities such as land and water conservation; wildlife and habitat protection conservation, rehabilitation and restoration; and infrastructure. It also includes supporting authorities such as research and innovation; enforcement; mechanisms of cooperation, good neighbor authority, and financial assistance; and volunteers (see SI S2 for a more comprehensive listing of relevant authorities).

\section{General authorities: land and water conservation}

Most federal agencies with jurisdiction over public lands and waters have been provided broad authority to manage, create agreements, and regulate the use of such land and waters. Many of them mandate or authorize protection, conservation, restoration, and enhancement of these lands. These terms are very broad or are not defined and rely on agency discretion, which provides flexibility to address the threats posed by invasive species. Some agencies have used their 
discretion to include invasive species under their definition of management (43 CFR 2812.0-5).

Some of these authorities explicitly include invasive species management (e.g., stewardship contracts for national forest or public land management including control of noxious and exotic weeds under 16 USC $\$ 6591 \mathrm{c}$, control of wildfires, insects, pest plants, and diseases in wilderness areas under 50 CFR 35.7, and removal of wild and exotic animals from US Army Corps of Engineers' (USACE) water resources projects under 36 CFR 327.11), while others provide discretion for agencies to take action as they see fit. Federal agencies have used such authorities to carry out invasive species EDRR. A good example is the National Park Service's (NPS) authority to regulate, prohibit, inspect, and decontaminate watercraft entering certain National Park System units (Department of the Interior 2018). Other agencies have been granted general authority for detection (e.g., monitoring and surveillance) and response (e.g., destruction and removal) (54 USC \$100101; 100751). NPS can destroy animals and plant life detrimental to the use of any National Park System unit (54 USC §100752) or remove timber to control insects and diseases (54 USC $\S 100753)$.

\section{General authorities: wildlife and habitat protection, conservation, rehabilitation, and restoration}

There are numerous authorities related to wildlife and habitat protection, conservation, rehabilitation, and restoration. As in the case of land and water conservation, these terms are broad or are not defined and rely on agency discretion. Wildlife and habitat protection, conservation, rehabilitation, and restoration can require prevention, control, and eradication of invasive species if they directly or indirectly impact wildlife and their habitats. Some authorities explicitly address invasive species, such as the Great Lakes Restoration Initiative (33 USC §1268), but most do not. In addition, there are also emergency restoration and conservation authorities that address natural disasters including invasive species (e.g., 7 CFR 701.2).

One of the major authorities for wildlife protection is the Endangered Species Act (ESA) of 1973 (16 USC $\$ 1531$ et seq.; 50 CFR pt. 17; 7 CFR pt. 355 ). ESA is a critical federal environmental statute that could have direct and indirect implications for invasive species.
This act provides for the conservation of threatened and endangered species of plants and certain animals. ESA requires federal agencies to ensure that governmental and non-governmental actions authorized, funded, or carried out by federal agencies are not likely to jeopardize the continued existence of listed threatened or endangered species or the destruction or adverse modification of their habitat. ESA could be used to prevent the introduction of invasive species that threaten listed species, as well as for direct actions against invasive species as part of endangered species recovery plans. These actions could include early detection and rapid response.

\section{General authorities: infrastructure}

Some federal agencies have authority to carry out or provide assistance for maintenance work to protect water, power, transportation, building, and housing infrastructure (Invasive Species Advisory Committee 2016). This work can include highway maintenance (USC Title 23), protection of navigable waters, river and harbor improvement, artificial reef management, dam protection, fishways construction, and maintenance of bridges over navigable waters (USC Title 33). In addition, there is authority for maintenance of reservoirs, irrigation works, and aging infrastructure (43 USC \$491-492; 43 USC $\$ 510$ b et. seq.), construction and maintenance of water conservation and utilization projects in the Great Plains (16 USC $\S \S 590 \mathrm{y}$ et. seq.), and authority for protection and preservation of historic property (54 USC $\$ 306101$ et. seq.). Federal agencies (e.g., US Department of Transportation) use discretion under such authorities to control certain invasive species, such as roadside vegetation. Similar discretion could be used for invasive species EDRR efforts to protect infrastructure.

\section{Supporting tools: research and innovation}

Basic and applied science are critical to understand, detect, manage, and eradicate invasive species. Innovative solutions are required to address invasive species that cannot be detected or eradicated by traditional methods (see Martinez et al. 2019, this issue; Reaser et al. 2019, this issue). As referenced above, there are numerous authorities allowing or funding research and innovation. Some federal 
agencies, like the US Geological Survey (USGS), have limited authority to address the management of invasive species, but play an integral role in conducting the science that management agencies need to inform EDRR efforts and decisions.

\section{Supporting tools: enforcement}

Enforcement can have dual meaning with regard to invasive species. On the one hand, it can provide for criminal or civil action (e.g., Lacey Act). On the other hand, enforcement authorities can provide for on the ground efforts such as inspection or seizure (e.g., PPA and AHPA). For the purpose of invasive species EDRR, on-the-ground enforcement is critical, and several federal authorities provide for enforcement. In addition, federal agencies can aid other federal agencies and subnational governments in the enforcement of certain authorities. As an example, USDA is authorized to cooperate with states or political subdivisions in the enforcement and supervision of a state's laws and ordinances on national forest system units (16 USC §551a; 36 CFR 241.1), NPS is authorized to cooperate with state law enforcement agencies to enforce state invasive species control laws within park units (54 USC §102701) or assist law enforcement on certain purposes outside park units (54 USC $\$ 102711$ ). DOI and Department of Commerce (DOC) can establish agreements for enforcement of federal and state laws related to water and lands under their jurisdiction for the protection of fish and wildlife resources (16 USC \$7421). Another example is the Department of Justice's authority to create a law enforcement task force in Hawaii to facilitate the prosecution of violations of federal and state law relating to the wrongful conveyance, sale, or introduction of nonindigenous plant and animal species (34 USC §12641; Resnik 2018). If federal agencies are authorized to enforce a subnational government's invasive species laws and regulations, this could expand their ability to carry out invasive species EDRR.

Supporting tools: cooperation mechanisms, good neighbor authority, and financial assistance

EDRR efforts require collaboration among national and subnational governments, as well as the private sector and other non-governmental entities. Most federal agencies have the authority to enter into contracts, grants, cooperative agreements, interagency agreements, awards, and memoranda of understanding (MOU) with other federal agencies, subnational governments, and other entities. This flexibility allows agencies to increase collaboration and can address federal gaps in capacity, resources, personnel, or authority. As an example, NPS currently has agreements to assist state agencies in providing inspection and decontamination of certain watercraft that may be transporting aquatic invasive species. At the local level, a number of federal agencies are involved in the work of cooperative invasive species management areas (CISMAs), cooperative weed management areas (CWMAs), and other cooperative stakeholder programs.

Agencies usually have general authority to enter into cooperation mechanisms, but there is also specific language for natural resources protection. As an example, land management agencies such as the Bureau of Land Management (BLM) and US Forest Service (USFS) have Good Neighbor Authority to enter into agreements with governors to carry out authorized restoration services including activities to treat insect and disease infected trees (16 USC $\S 2113 \mathrm{a})$. NPS has similar language for the protection of natural resources on park units (54 USC \$101702). In addition, there are specific mandates to individual NPS park units that require coordination with adjacent land owners for invasive species management as well as discretion to collaborate and create partnerships to control and manage invasive species to protect certain public waters and wildlife (P.L. 116-9). Another example includes the authority for BLM to cooperate with subnational governments for noxious weed assessment and control (43 CFR 4120.5-2).

There is also legislation that allows states to create interstate agreements and compacts (agreements on matters in which there is a common concern) with other states to perform conservation efforts. Some examples include forest and water conservation agreements (16 USC §552), compacts for invasive jellyfish (16 USC §1204), and emergency management assistance compacts (6 USC \$761). Statutes that authorize interstate agreements and compacts without the need of Congressional approval strengthen states' abilities to address invasive species with fellow states/ territories. Compacts are currently used to address invasive species, such as the invasive species program 
under the Tahoe Regional Planning Agency (P.L. 96-551).

Finally, it should be noted that federal laws can also preempt subnational governments from taking certain actions, such as enacting or enforcing certain laws and regulations. Some invasive species authorities explicitly preempt state action unless consistent with federal regulations or a demonstrated special need (e.g., PPA 7 USC §7756).

\section{Supporting tools: volunteers}

Effective and long-term EDRR efforts require human capital beyond current federal staffing capability. Besides cooperation agreements with subnational governments and other entities for staffing support, there are multiple authorities allowing federal agencies to recruit and train volunteers for diverse functions. Some of these functions relate to fire prevention and conservation work. If federal agencies have authority to carry out EDRR efforts, volunteers could be used for support as permitted by law.

Category 4: Constraining authorities

Category 4 includes legislation and legal requirements that both provide essential protection for natural and cultural resources and potentially constrain EDRR efforts. For example, requirements for environmental assessments may delay responses or there may be limitations on particular control measures that can be used during a response effort. In order to ensure due diligence, transparency, and environmental protection, federal actions, including those related to invasive species management, need to comply with these environmental laws and regulations. However, advanced planning and consideration can allow EDRR in light of these laws and regulations.

This section includes authorities related to the National Environmental Policy Act (NEPA), the Federal Insecticide, Fungicide, and Rodenticide Act (FIFRA), ESA National Historic Preservation Act (NHPA), and the Clean Water Act (CWA). It is important to note that these pieces of legislation serve an important function for protecting wildlife, human health, and other environmental and cultural concerns. This review is not intended as a critique of those provisions, but instead a recognition of their intersection with EDRR activities.
International commitments, subnational government's rights, and individual rights could also hinder EDRR actions but they are beyond the scope of the assessment.

\section{National Environmental Policy Act}

NEPA (42 USC $\$ 4321$ et. seq.,40 CFR ch.V) requires federal agencies to: analyze the physical, social, and economic effects associated with proposed plans and decisions involving federal agencies or funds; consider reasonable alternatives to the action proposed; and document the results of the analysis. The provisions of NEPA and the Council on Environmental Quality (CEQ) implementing regulations apply to invasive species control and management given the potential for significant impacts to the environment. In this regard response actions on federal lands or using federal funds may require an Environmental Assessment (EA) or Environmental Impact Statement (EIS). Most agencies have their own NEPA implementing procedures (e.g., DOI 43 CFR pt. 46; USDA-APHIS 7 CFR pt. 372; USDA-ARS 7 CFR pt. 520; USDA-FSA 7 CFR pt. 799; USACE 33 CFR pt. 230; FS 36 CFR pt. 220; USPS 39 CFR pt. 775).

EAs and EISs require collection of data and public participation. If EAs and EISs related to EDRR activities are not considered in advance such efforts may be compromised as species can become established or continue to spread while those processes are completed. This is especially true for organisms with greater movement potential (e.g., animals). Compliance with NEPA can also be achieved by not categorizing an action as a "major federal action," streamlining the NEPA process, and/or by creating Categorical Exclusions (CEs) for classes of activity that won't have an adverse environmental impact. CEs can be established through legislation, although NEPA allows federal agencies to create CEs for very specific actions or a broader class of actions. For example, in October 2015, a CE for listing injurious species was developed, allowing the USFWS to streamline the listing process for injurious wildlife under the Lacey Act (Federal Register 2015). Similarly, there are examples where legislation specifically requires agencies to create a $\mathrm{CE}$ for certain invasive species related activities (e.g., greater sage-grouse [Centrocercus urophasianus] and mule deer [Odocoileus hemionus] habitat under 16 USC §6591). Other agencies, like 
BLM, USACE and USFS, have developed CEs for invasive species management, and APHIS has incorporated CEs for routine measures into its implementing regulations for NEPA. Currently, more consideration is being given to the need for CEs that enable rapid response actions beyond what may already be allowed in the control context. Finally, NEPA allows waivers of EIS in certain emergencies (40 CFR 1506.11), although to our knowledge they have not been used for invasive species actions.

\section{Federal Insecticide, Fungicide, and Rodenticide Act}

Under FIFRA, EPA administers the federal registration process for pesticides (7 USC $\S \S 135$ et seq., 40 CFR ch.I subch.E). FIFRA requires pesticide registration, establishes requirements, and limits the conditions under which they may be used. Under the definition of pest, some of these pesticides may be used to respond to invasive species (7 USC $\$ 136,40$ CFR 152.5). Pesticide registration can be an expensive and time consuming process (ELI 2007) which could limit the timeliness of rapid responses. This can include the registration of pesticides by EPA, as well as their subsequent review and approval for use by federal land management agencies. Note that not all invasive species response tools are regulated under FIFRA such as biological control agents, animal drugs, pheromones and pheromone traps, and minimum risk pesticides (40 CFR 152.20-152.30).

EPA has the discretion to exempt federal and state agencies from the provisions of this act through certain emergency exemptions (7 USC §136p, 40 CFR pt. 166.1). These emergency exemptions include a quarantine exemption to control the introduction or spread of any pest that is an invasive species, or is otherwise new to or not known to be widely prevalent or distributed within the US and its territories (40 CFR 166.2). It also provides a public health exemption to control a pest that will cause a significant risk to human health, an exemption to avert significant economic loss or risk to certain biodiversity and the environment, and a crisis exemption when there is insufficient time to authorize a specific quarantine or public health exemption (40 CFR 166.2).

\section{Endangered Species Act}

The ESA provides for the conservation of threatened and endangered species of plants and certain animals (see Category 3 above). ESA compliance could hinder agency actions associated with invasive species EDRR. This act prohibits certain actions and requires consultation, biological assessments, and issuance of permits for actions that might affect such species or their habitats. These requirements could limit available actions and affect the timeliness of EDRR efforts if they pose a risk to threatened or endangered species. The act and its regulations provide for certain waivers in presidentially declared emergencies and other emergency situations where the life or health of an endangered animal is threatened and no reasonable alternative is available (50 CFR 17.21-17.22; 50 CFR 17.31). Certain invasive species related activities are exempt from the incidental taking of a limited number of threatened wildlife under regulation (50 CFR 17.40, 17.41, 17.42, 17.47).

\section{National Historic Preservation Act}

The NHPA of 1966 sets forth federal agencies' responsibilities with respect to the preservation of historic property. Compliance with Section 106 of NHPA requires federal agencies to take into account the effects of their undertakings on historic properties through a consultation process, which provides for public involvement and allows the Advisory Council on Historic Preservation an opportunity to comment on the proposed undertaking (54 USC \$306107306108, 36 CFR 800.1 et. seq.). Although the Section 106 process is designed to ensure that federal agency decisions take historic properties into account, compliance with its requirements could hinder EDRR efforts by impacting the timeliness of actions. Federal agencies may be exempted from certain provisions of the NHPA's preservation responsibilities, but this does not apply to their responsibilities under Section 106. Program alternatives to full Section 106 consultation may be available, including exemptions and alternative compliance procedures. However, these may only be implemented by agencies after complying with 
regulatory prerequisites for such alternatives (54 USC $\$ 306108,306112,36$ CFR 800.12). Absent a program alternative, federal agencies need to determine whether the proposed undertaking has the potential to adversely affect historic properties. If so, they would need to start a Section 106 consultation to determine whether any historic properties may be adversely affected by the proposed undertaking and whether those adverse effects may be resolved through agreement of the consulting parties prior to undertaking EDRR efforts. As mentioned, this could delay or constrain response alternatives and timeliness of actions.

\section{Clean Water Act}

The Clean Water Act of 1972(33 USC $\$ 1251$ et. seq., 40 CFR ch.I subch.D) prohibits the discharge of "pollutants" through a "point source" into a water of the US without a National Pollutant Discharge Elimination System (NPDES) permit. The term "pollutant" includes dredged spoil, solid waste, incinerator residue, sewage, garbage, sewage sludge, munitions, chemical wastes, biological materials, radioactive materials, heat, wrecked or discarded equipment, rock, sand, cellar dirt, and industrial, municipal, and agricultural waste discharged into water (33 USC $\$ 1362$ ). If EDRR actions involve the addition of a "pollutant" from a point source, then a permit is required. One example would be a pesticide requiring a Pesticides General Permit for invasive species eradication and control (Grad 2018a). If NPDES permitting is not considered prior to EDRR efforts, this could delay efforts or reduce the availability of tools or actions.

While EDRR activities are intended to protect natural, economic, and other resources, their conduct does not exempt them from compliance with other environmental statutes. Failure to address such environmental compliance prior to EDRR efforts might be one of the most limiting factors of success, regardless of the explicit or supporting authorities that a federal agency has. Some agencies have addressed these issues through the consideration and/or development of "hypothetical" EAs, programmatic EIS as well as CEs that take various contingencies into account should response actions be required (Grad 2018b). In this respect, table top EDRR exercises can be useful in determining the necessary legal requirements at the federal, state, and local levels. Finally, many of these statutes allow for exemptions in case of emergencies. This may be another area where engagement with federal agency solicitors could be useful to outline when and how they might apply to emergency response actions to invasive species.

\section{Key findings and conclusion}

Looking across the four broad categories of relevant authorities, the following section summarizes the general findings and concludes with recommendations to advance the legal position of federal agencies in conducting EDRR activities. For more specific guidance on authorities see Burgos-Rodríguez and Burgiel (2019, this issue).

Legal Patchwork: As is the case with US law regarding invasive species in general, there is no single authority that encompasses EDRR for all invasive species. Most of the statutes discussed herein were not explicitly intended to address EDRR for invasive species. The result is a patchwork of relevant authorities and their concomitant regulations, policies, and programs that address or have been applied to various aspects of the EDRR continuum. These authorities approach EDRR, sometimes directly and more often indirectly, from multiple angles, such as

- impacted taxa (e.g., plants, livestock)

- harmful taxa (e.g., noxious weeds) and species (e.g., brown tree snake)

- impacted ecosystems (e.g., forests, rangelands)

- jurisdictions (e.g., National Forests, BLM lands, NPS units)

- pathways (e.g., ballast water, mail inspection)

- agencies (e.g., APHIS, USFWS, USCG)

PPA and AHPA are the most comprehensive pieces of legislation that deal with invasive species, yet they are largely limited to agricultural concerns (e.g., PPA has a wider remit to look at impacts on forests and other ecosystems, but that is often done through the lens of potential commercial impacts, particularly on agriculture). Outside of PPA and AHPA, coverage of invasive species that impact natural areas, wildlife health, infrastructure, and other gaps is fractured as EDRR and emergency elements are restricted to specific sectors, pathways, or species. This is further 
exacerbated by the fact that rarely do those more specific pieces of legislation directly address the full range of EDRR actions, with rapid response elements being the most common omission.

Theoretically, legislation focused on disasters, public health, and other emergencies may also be applied to invasive species, but that would only be in the most extreme cases of national or subnational emergencies. Their broader benefit may be as positive models for EDRR in other sectors given their focus on establishing preparedness, detection, assessment, and response capabilities. The Stafford Act, Homeland Security Act, and the Public Health Safety Act show how a statute can serve as a core framework for EDRR that is built on and amended over time by additional pieces of legislation. Note that some states have declared invasive species emergencies under state laws but have not triggered relevant federal laws (State of Montana Office of the Governor 2016). The PPA and AHPA are a step in this direction but they are singularly tied to USDA, and would need significant consideration to effectively integrate agencies, species, and impacted areas not under USDA's jurisdiction.

Agency Discretion: Recognizing that there are significant gray areas in the interpretation and application of available authorities, agencies can avail themselves of their legal discretion to take action where consistent with their mission and authorities. Such discretion is greater when dealing with federal lands, waters, and preempted areas of legal authority. Agency solicitors could examine existing flexibilities built into the law or ambiguities where terms are not explicitly defined. For example, this could include: the development of CEs and other means to expedite NEPA and other environmental compliance measures that might hamper response; interpretation of how directives to prevent or control invasive species factor into the elements of EDRR; interpretation of conservation and maintenance authorities; or definition of what constitutes an emergency in the invasive species context. Such an approach will provide some measure of relief towards addressing gaps, but cannot in itself exceed their given authority or make up for the lack of an overarching EDRR authority and would require a degree of internal political will and leadership to prioritize and accomplish.

Environmental compliance Of particular importance to this analysis are those laws requiring compliance with various environmental and public health regulations. While not viewed as invasive species regulations, they can have a major impact on the conduct of invasive species control and management, particularly in the context of rapid response. Response efforts can be hindered by mandatory administrative steps. Some of the disaster and emergency statutes do include exceptions for such compliance in emergency situations, however those exemptions are not uniformly carried through legislation that more specifically relates to invasive species. The review of agencies' NEPA implementing regulations, the development of any advanced planning on CEs and programmatic EIS, and the consideration of pesticide registration requirements under FIFRA could facilitate some progress in this area.

Cooperation EDRR generally involves a large suite of actors, not just federal agencies working in isolation. Agencies have a broad degree of flexibility in how they can work with subnational governments and other non-governmental entities in support of activities that address potential impacts on federal lands and, in some cases, non-federal lands as well. The other assessments in this volume detail more specifically where this type of cooperation can occur (e.g., detection, identification, information sharing, incident command system). In cases where federal agencies lack authority, they may be able to work with subnational governments under the umbrella of their authorities, which may be complementary or broader.

Recommendations Given their breadth of impacts over time, space, and sectors, invasive species already pose a sufficient threat to justify their separate recognition in law. However, it's possible that the breadth of impacts has also served to fragment legal responses in the United States. As noted above, outside the United States, other countries and regional entities, like New Zealand and the EU have in recent years worked to consolidate legal authorities and institutional responsibilities relating to invasive species to ensure more comprehensive coverage and efficient use of resources. Whether such an approach, for invasive species management in general or EDRR more specifically, is viable in the United States is an open question. But the alternative of providing patches whenever a new gap or threat arises may be equally untenable over the long term.

The accompanying guidance note on authorities in this volume (Burgos-Rodríguez and Burgiel 2019, this 
issue) provides some thoughts for advancing agency capacity to more fully implement EDRR from a legal perspective. Drawing from this review of authorities, some of those central activities would include the following:

1. Considering how to integrate and add to authorities in a more comprehensive manner that allows for improvements with amendments over time.

2. Providing for emergency designation of harmful or potentially harmful nonnative species without additional delays for issuing regulations or processing undue assessments before engaging in EDRR.

3. Using agency discretion to specify and streamline available agency measures to conduct EDRR activities.

4. Using broad authorities to enter into cooperation with subnational and non-governmental entities to cooperate on EDRR activities, particularly in areas where there are gaps at the federal level.

5. Leveraging supporting authorities to enable EDRR, including in areas addressed by other assessments (e.g., information sharing, research, technology development, use of challenge prizes).

6. Acting in accordance with EO 13112, as amended by 13751 , to use relevant agency authorities to rapidly detect and respond to invasive species.

Invasive species EDRR must work across multiple jurisdictions and authorities. Although the task might seem daunting, the incremental impacts of invasive species on our nation requires further reinforcement of the complex legal framework that underpins the ability of federal agencies to effectively detect and respond to these threats.

Acknowledgements This document advances Action 5.1.6 of the 2016-2018 NISC Management Plan. The authors thank the contribution of federal employees who provided responses to agency surveys and supplemental inquiries, as well as Michael Bean, Russell Husen, Craig Martin, Marshall Meyers, Susan Pasko, Sara Posria, Jamie K. Reaser, Laura Meyerson, and Dan Simberloff for their comments, materials, and reviews. Additional support for the assessment was provided by Kelsey Brantley, Jason Kirkey, Jeff Morisette, and Sarah Veatch. The paper's contents are a scholarly review of federal laws and are not intended as a definitive legal statement by agencies or their solicitors. Any errors or misstatements are the sole responsibility of the authors. Financial support for this project was provided through Service First funding to the NISC
Secretariat. Contributions by Jhoset Burgos-Rodríguez were largely made while staffing the NISC Secretariat.

Open Access This article is distributed under the terms of the Creative Commons Attribution 4.0 International License (http:// creativecommons.org/licenses/by/4.0/), which permits unrestricted use, distribution, and reproduction in any medium, provided you give appropriate credit to the original author(s) and the source, provide a link to the Creative Commons license, and indicate if changes were made.

\section{References}

Boyd IL, Freer-Smith PH, Gilligan CA, Godfray HCJ (2013) The consequence of tree pests and diseases for ecosystem services. Science 342:1235773

Burgiel SW (2019) The incident command system: a framework for rapid response to biological invasion. Biol Invasions. https://doi.org/10.1007/s10530-019-02150-2

Burgos-Rodríguez J, Burgiel SW (2019) Federal legal authorities: guidance for application to the early detection of and rapid response to invasive species. Biol Invasions. https:// doi.org/10.1007/s10530-019-02149-9

Committee on the Movement of Aquatic Invasive Species onto and off of Federal Lands and Waters (2015) Federal policy options: addressing the movement of aquatic invasive species onto and off of federal lands and waters. Aquatic Nuisance Species Task Force and National Invasive Species Council. https://www.anstaskforce.gov/Documents/ 2015-0828-Federal-Lands-Policy-Options-for-

Addressing-the-Movement-of-AIS-onto-and-off-ofFederal-Lands.pdf. Accessed 1 Oct 2018

Corn ML, Johnson R (2013) Invasive species: major laws and the role of selected federal agencies. Congressional Research Service Report:R43258. Washington

Corn ML, Johnson R (2015) Invasive species: issues in brief. Congressional Research Service Report:R44049. Washington

Environmental Law Institute (2002) Halting the invasion: state tools for invasive species management. ELI, Washington

Environmental Law Institute (2004) Invasive species control: a comprehensive model state law. ELI, Washington

Environmental Law Institute (2010) Status and trends in state invasive species policy: 2002-2009. ELI, Washington

Environmental Law Institute, The Nature Conservancy (2007) Strategies for effective state early detection/rapid response programs for plant pests and pathogens. ELI, Washington

European Commission (2014) Regulation of the European Parliament and of the Council on the prevention and management of the introduction of invasive alien species, PE-CONS 70/14. Brussels

Executive Office of the President (1999) Executive Order 13112, 64 FR 6183-6186, 8 Feb 1999

Executive Office of the President (2016) Executive Order 13751, 81 FR 88609-88614, 5 Dec 2016

Executive Office of the President (2018) National Biodefense Strategy 
Grad FP (2018a) 4 Treatise on Environmental Law §8.04, Release No.83

Grad FP (2018b) 4 Treatise on Environmental Law $\$ 9.02$, Release No.83

Graham JC (2011) Snakes on a plain, or in a wetland: fighting back invasive nonnative animals-proposing a federal comprehensive invasive nonnative animal species statute. Tulane Environ Law J 25(1):19-81

Invasive Species Advisory Committee (2016) Invasive species impacts on infrastructure. Washington

Johnson R, Crafton RE, Upton HF (2017) Invasive species: major laws and the role of selected federal agencies. Congressional Research Service Report:R43258. Washington

Martinez B, Reaser JK, Dehgan A, Zamft B, Baisch D et al (2019) Technology innovation: advancing capacities for the early detection of and rapid response to invasive species. Biol Invasions. https://doi.org/10.1007/s10530-01902146-y

McNeely JA (2001) The great reshuffling: human dimensions of invasive alien species. IUCN, Gland

Meyerson LA, Reaser JK (2003) Bioinvasions, bioterrorism, and biosecurity. Front Ecol Environ 1(6):307-314

Miller ML (2003) NIS, WTO, SPS, WIR: does the WTO substantially limit the ability of countries to regulate harmful nonindigenous species? Emory Int'l L Rev 17:1059

Miller ML (2004) The paradox of us alien species law. In: Miller ML, Fabian RN (ed) Harmful invasive species legal responses. Environmental Law Institute, Washington

Miller ML, Fabian RN (2004) Harmful invasive species legal responses. Environmental Law Institute, Washington

Morisette JT, Reaser JK, Cook GL, Irvine KM, Roy HE (2019) Right place. Right time. Right tool: guidance for using target analysis to increase the likelihood of invasive species detection. Biol Invasions. https://doi.org/10.1007/s10530019-02145-z

National Invasive Species Council (2001a) Appendix 2. In: Meeting the invasive species challenge: management plan. National Invasive Species Council, Washington

National Invasive Species Council (2001b) Appendix 3. In: Meeting the invasive species challenge: management plan. National Invasive Species Council, Washington

Office of Technology Assessment (1993) Harmful non-indigenous species in the United States. Office of Technology Assessment, Washington

Otts S, Nanjappa P (2016) Model regulation for state watercraft inspection and decontamination programs. National Sea Grant Law Center, University

Pejchar L, Mooney HA (2009) Invasive species, ecosystem services and human well-being. Trends Ecol Evol 24(9):497-504

Pimentel D (ed) (2011) Biological invasions: economic and environment costs of alien plant, animal, and microbe species. CRC Press, Boca Raton
Pimentel D, Zuniga R, Morrison D (2005) Update on the environmental and economic costs associated with alien-invasive species in the United States. Ecol Econ 52(3):273-288

Public Act (1993) Biosecurity Act 1993 No 95. http://www. legislation.govt.nz/act/public/1993/0095/latest/ DLM314623.html. Accessed 19 Sept 2019

Public Act (1996) Hazardous Substances and New Organisms Act 1996 No 30. http://www.legislation.govt.nz/act/public/ 1996/0030/latest/DLM381222.html. Accessed 19 Sept 2019

Pyšek P, Richardson DM (2010) Invasive species, environmental change and management, and health. Annu Rev Environ Resour 35:25-55

Reaser JK, Burgiel SW, Kirkey J, Brantley KA, Veatch SD, Burgos-Rodríguez J (2019) The early detection of and rapid response (EDRR) to invasive species: a conceptual framework and federal capacities assessment. Biol Invasions. https://doi.org/10.1007/s10530-019-02156-w

Resnik JR (2018) Biodiversity under siege, invasive animals and the national park service: a state of the knowledge report. National Parks Service, Fort Collins

Shine C, Williams N, Gündling L (2000) A guide to designing legal and institutional frameworks on alien invasive species. IUCN, Gland

State of Montana Office of the Governor (2016) Executive Order 18. Proclaiming and Invasive Species Emergency to Exist in the State of Montana

US Department of Defense (2017) Invasive species challenges and solutions. http://www.dodinvasives.org/Invasives_ and_Military_Feb2017.pdf. Accessed 12 April 2018

US Department of the Interior (2016) Safeguarding America's lands and waters from invasive species: a national framework for early detection and rapid response. Office of Technology Assessment, Washington

US Department of the Interior, Office of the Solicitor (2018) Letter regarding National Park Service Authority to Regulate Aquatic Invasive Species

US Government Accountability Office (2001) Invasive species: obstacles hinder federal rapid response to growing threat. US General Accounting Office Report to Congressional Requester:GAO-01-724. Washington

Wingfield MJ, Brockerhoff EG, Wingfield BD, Slippers B (2015) Planted forest health: the need for a global strategy. Science 349:832-836

Young TR (2006) National and regional legislation for promotion and support to the prevention, control, and eradication of invasive species. The World Bank, Washington

Publisher's Note Springer Nature remains neutral with regard to jurisdictional claims in published maps and institutional affiliations. 